\title{
Genetic recurrent myoglobinuria
}

INSERM

\section{Source}

INSERM. (1999). Orphanet: an online rare disease and orphan drug data base. Genetic recurrent myoglobinuria. ORPHA:99845

Genetic recurrent myog lobinuria is an inborn error of metabolism characterized by abnormal urinary excretion of myog lobin due to acute destruction of skeletal muscle fibers. 